\title{
HONORIFIC STATUES FOR GAIUS AND LUCIUS CAESAR
}

SŁOwA KLuCzowe: posagi Gajusza i Lucjusza; zwyczaj wznoszenia posągów KEYwOrDs: statues Gaius and Lucius; the custom of erecting statues

In 17 BCE Augustus adopted Gaius and Lucius, the sons of Agrippa and Julia. Even though formally, the adoption made them his private heirs, in the light of the traditions of the Republic, to the Roman society the two boys also naturally became the heirs to the Princeps' friends, clients and political connections, which made them particularly suitable for replacing Augustus in the future on the political scene (Cassius Dio: 195; Dettenhofer 2000: 163; Severy 2003: 71; Veyne 2008: 15). Thus to their contemporaries it must have been obvious that one of the brothers would one day become Emperor. Including the two young men in gens Iulia and conferring on them the status of heirs to the throne (Kuhoff 1993: 60; Zanker 1999: 220) ${ }^{1}$ was reflected in how they were presented to the public. The brothers were also showered with prestigious honours, granted by the Senate, the equites and local authorities among others. In this paper, my focus will be on statues as one of the many forms of honouring Augustus' sons. I am primarily interested in the historical context and circumstances of their erection, as well as who founded them. My purpose is not to catalogue all statues to Gaius and Lucius, but rather to list those examples I believe the most typical.

The earliest statues in honour of the young Caesares were dedicated in the East between 16 and 13 BCE, or soon after their adoption, prompted by Agrippa and Julia arriving in the Eastern provinces (Reinhold 1933: 106-123; Raddaz

\footnotetext{
${ }^{1}$ „Heir to the throne" is a working term absent from any ancient sources, which I here use in reference to those members of the imperial family that Augustus publicly presented as his successors.
} 
1984: 419-475; Halfmann 1986: 164-166; Sawiński 2004: 244-246)². To the inhabitants of the region, the visit from Augustus' son-in-law and daughter was an occasion to emphasise their loyalty to and affection for the Emperor's family by suitably honouring its most prominent members. The statues erected then in honour of Gaius and Lucius were an integral part of statuary groups dedicated to the domus Augusta by the cities of the region. Among them was an interesting statuary cycle set up in Thespiae in Boeotia, dated to between 16 and 13 BCE (Rose 1997: 149-151, cat. 82; Boschung 2002: 144-145). Those dedication inscriptions that survive indicate that it was founded by the local Assembly and included the statues of Agrippa, Julia, Gaius and Lucius Caesar, Agrippina, and Livia, all of them probably placed in the local sanctuary to the Muses. Unfortunately we have no details of their appearance, since they have not been preserved, forcing us to make do with hypothetical reconstructions. Such a reconstruction was attempted by Brian Rose in his interesting book on statuary groups erected in honour of the members of the Julio-Claudian dynasty. It is his opinion that central in the group in question was a statue of Julia, with statues of Gaius and Lucius on her sides, flanked by Livia further to the right, while Agrippa stood further left with the young Agrippina in his arms. This scholar assumes that Gaius and Lucius Caesar, while still young children at the time, had free-standing statues rather than being held by Julia in her arms (Rose 1997: 150-151). As Rose writes, including images of children among the statues of adult members of the reigning dynasty was a significant innovation as far as ways of honouring the ruling elite went, as we have no knowledge of any public images of children of monarchs of the Hellenistic period (Rose: 13).

For another example, let us turn towards a statuary group erected by the inhabitants of Paros, probably between 17 and 2 BCE. The preserved foundation inscriptions indicate that it included three statues, of which two certainly depicted Gaius and Lucius Caesar. It is not known of whom the third statue was, as the inscription relating to it is badly damaged, but it could be of Agrippa Postumus or of Julia. The latter seems more likely, considering we have no statues of Postumus from the Eastern provinces (Rose: 156-157, cat. 92). As was the case with the Thespiae group discussed above, the Paros statues of the young Caesars have not survived.

The year 5 BCE was of particular importance in Gaius' career. It is then that he donned his toga of manhood (toga virilis), received the honorary title of princeps iuventutis, and was designated for consulship (Res gestae divi Augusti, XIV, 1-2;

\footnotetext{
${ }^{2}$ Agrippa was sent to the East to inspect the provinces and vassal-kingdoms there. For his activities in the region between the years 17 and 13 BCE.
} 
Tacitus, Annales, I, 3; Cassius Dio, LV, 9; Zonaras, X, 35; Suetonius, Augustus, XXVI, 2-3). This event, important to the whole imperial house, were celebrated throughout the Empire, among other ways by erecting further statues to him. We know from epigraphical sources that the inhabitants of Sardes resolved to make the day when Augustus' elder son assumed hi toga virilis into a public festival of their city (Rose 1997: 179-180) (Inscriptiones Graecae ad res romanas pertinentes, IV, 1756, 6-11); the youth was also given a statue, placed next to that of Augustus in the local temple to the Princeps (Rose 1997: 180). It is probably on the same occasion (as indicated by Gaius' titulature in the inscription) that a statuary group was set up on Pagus Stellatinus in Italy. The group included statues of Gaius, Lucius and Augustus. According to its dedication inscriptions, it was founded by a P. Sergius Rufus and T. Braetius Rufus, the magistri of that Italian colony. It is supposed that the statues made an integral part of a shrine erected by the two personages. Based on the number of Augustus' tribunicia potestas quoted in the inscription, the group can be dated to 4 or 3 BCE (Rose 1997: 99, cat. 27). It is worth emphasising that in this case honouring Gaius became an occasion to similarly honour his younger brother.

In $2 \mathrm{BCE}$ it was Lucius Caesar's turn to assume the toga virilis. Just as Gaius before, Lucius was designated consul and received the title (Fig. 1) princeps iuventutis (Bowersock 1984: 173; Rose 1997: 18; Zanker 1999: 224, 261). It is probably in connection with that event that a statue group in honour of Augustus' sons was erected in Rome itself for the first time that we know of. This time, then, it was an important moment in Lucius' life that offered an occasion to honour Gaius. B. Rose assumes that the brothers' statues were placed in front of the temple to Portunus in Forum Boarium, as in the 16th century their pedestals were discovered there, bearing dedication inscriptions in the honour of the young Caesares (Rose: 17, 106-107, cat. 34). That location does seem likely; however, considering the phenomenon of the so-called wandering inscriptions, there can be no absolute certainty in the matter. In view of the titulature applied there in referrence to Augustus' sons, we may conclude that the statues were dedicated shortly after $2 \mathrm{BCE}$, but nothing is known about their founders.

Gaius Caesar's stay in the East in the years $1 \mathrm{BCE}-4 \mathrm{CE}$ in connection with his mission in the region provided the inhabitants of its provinces with another opportunity for honouring the son and prospective heir of the Princeps (for Gaius` mission in the East - Zetzel 1970; Romer 1979; Herz 1980; Dąbrowa 1998: 203-205). It is to that period that we date statues to Gaius erected, among other places, in Athens, Sparta and Lindos on Rhodes. The Athenian monument was most spectacular. A temple to Ares was built in the agora there to house the 
statue of Gaius, styled ,the new Ares" in the honorific inscription. Interestingly, the new temple was made of materials obtained from dismantling a fifth-century temple to the same god which had stood in one of the Attic demes. The undertaking is usually seen in connection with Gaius' planned Parthian campaign, since the young man was widely proclaimed the new conqueror of the Parthians (Bowersock 1984: 173; Rose 1997: 18; Zenker 1999: 224, 261). In Sparta, the statue of Gaius was placed at the theatre. It was later accompanied by one of Lucius, probably added only after his death. In both cases, the decision to put them up was taken by the local authorities (Rose: 149, cat. 81). In Lindos, the statues of the young Caesares were placed in front of the entrance to the local temple to Athena (Rose: 154, cat. 88). Unfortunately, none of the statues discussed above and presumably founded in connection with Gaius' time in the East survive.

Before moving on to conclusions, I would like to draw the reader's attention to certain statuary groups erected in connection with the two Caesares' premature deaths. They are but one of many ways in which Augustus' sons were honoured posthumously (Sawiński 2012: 44-48). Let the statues set up to the brothers in Casinum in Italy serve as an example. It is supposed that they stood at the theatre, a guess supported by a head found there and identified as part of a statue of Lucius. Since the back of the head is not quite finished, B. Rose came forward with the theory that the images could have been placed in recesses of the skene (scaenae frons) of the theatre (Rose: 86-87, cat. 6). Other statues worthy of note are those used to honour the dead Caesares in Corinth, luckily both of them preserved, that of Gaius complete, whereas of that of Lucius, the head and torso remain (Fig. 2 and Fig. 3). From them we know that the brothers were depicted in the liking of the Dioscuri, in heroic style, naked save for cloaks, draped over the left shoulder and around the left forearm (Rose: 138-139, cat. 69). It is that mode of presentation that allows for the conclusion that the statues are posthumous. For as B. Rose notes, up till the reign of Claudius, in Roman colonies (such as Corinth), the heroic nudity was reserved for images of the dead. The sculptures were discovered in the exedra of the local Basilica Iulia. Latest research dates that building to as late as the reign of Tiberius, which is probably when they were moved there; we do not know, however, where they were located originally (Rose: 139).

It is also possible that an armoured statue based on the sculpture of Augustus of Prima Porta, found at the theatre in Jol-Caesarea (the seat of rulers of Romedependent Mauritania, modern Cherchell in Algeria) in fact represents Gaius. The statue was probably founded shortly after Gaius' death by Juba II. The ima- 
ges decorating the armour (Fig. 4) indicate that it was to commemorate young Caesar's successes in the Armenian-Parthian campaign. In the centre there is Gaius, shown according to the heroic convention with his torso nude, handing a figurine of Victory with a tropaeum to Venus, who faces him. Behind Gaius there appears Victory personified, holding above his head the oak wreath (corona civica) as the mark of the Julian dynasty. Below that central scene one sees two centaurs, one holding a horn of plenty (cornu copiae), the other a ship's helm, a clear reference to the consequences of Augustus' victory at Actium, so fortunate for the state. In that context, as Paul Zanker rightly notes, Gaius' success was painted to be the continuation of the blessed era begun by that victory. The upper part of the scene showed Mars wearing a helmet and armour, while on the leather overlays there appeared bearded heads of barbarians symbolising the defeated Parthians and Armenians (Zenker 1999: 225-226).

In summary, it ought to be emphasised that the custom of erecting honorific statues to heirs to the throne started under Augustus became common practice during the reigns of later Julio-Claudian emperors. The available source material indicates that statuary groups dedicated to Gaius and Lucius would be founded by the local elites or local authorities (that is, the Council or the Assembly), and there are no grounds for assuming any interference from the Emperor or the Senate in that regard. I believe that inhabitants of the provinces knew perfectly well how to fittingly honour the most eminent members of the domus Augusta. The high rank of those honours is borne out, among other things, by the locations of the statues, which were usually those with the most prestige in their respective cities of Italy and the provinces, that is the agora, the theatre or a temple. Only the emperor and his closest family were honoured in this way.

dr Paweł Sawiński

Adam Mickiewicz University

Faculty of Pedagogy and Art

Zakład Ochrony Dziedzictwa Kulturowego I Komunikacji Międzynarodowej

ul. Nowy Świat 28-30

62-800 Kalisz 


\section{BiBLIOGRAPHY}

\section{Sources}

Cassius Dio, The Augustan Settlement (Roman History 53 - 55.9), edited with translation and commentary by J. W. Rich, Aris \& Philips, Warminster 1990.

\section{Literature}

Boschung D. (2002), Gens Augusta. Untersuchungen zu Aufstellung, Wirkung und Bedeutung der Statuengruppen des julisch-claudischen Kaiserhauses, Zabern, Mainz am Rhein.

Bowersock G. (1984), Augustus and the East. The Problem of Succession, [in:] Caesar Augustus. Seven Aspects, eds. F. Millar, E. Segal, Oxford University Press, Oxford, pp. 169-188.

Dąbrowa E. (1998), The Governors of Roman Syria from Augustus to Septimius Severus, Habelt, Bonn.

Dettenhofer M. H. (2000), Herrschaft und Widerstand im augusteischen Principat. Die Konkurrenz zwischen Res Publica und Domus Augusta, Steiner, Stuttgart.

Halfmann H. (1986), Itinera principum. Geschichte und Typologie der Kaiserreisen im römischen Reich, Steiner, Stuttgart.

Herz P. (1980), Der Aufbruch des Gaius Caesar Caesar in den Osten, „Zeitschrift für Papyrologie und Epigraphik”, t. 39, pp. 285-290.

Kuhoff W. (1993), Felicior Augusto melior Traiano. Aspekte der Selbstdarstellung der römischen Kaiser während der Prinzipatszeit, Lang, Frankfurt am Main.

Reinhold M. (1933), Marcus Agrippa. A Biography, Humphreys Press, Geneva-New York.

Roddaz J. M. (1984), Marcus Agrippa, Ėccole Française de Rome, Roma.

Romer F. E. (1979), Gaius Caesar's Military Diplomacy in the East, „,Transactions and Proceedings of the American Philological Association”, t. 109, pp. 199-214.

Rose B. (1997), Dynastic Commemoration and Imperial Portraiture in the Julio-Claudian Period, Cambridge University Press, Cambridge.

Sawiński P. (2004), Agrippa's Mission in the East, „Eos” 91, fasc. 2, 2004, pp. 242-250.

Sawiński P. (2012), Pogrzeby i formy pośmiertnego uhonorowania członków rodziny cesarskiej w okresie pryncypatu Augusta i Tyberiusza (Funerals and Forms of Posthumous Honouring of Imperial Family Members During the Principate of Augustus and Tiberius'), „Studia Europaea Gnesnensia”, t. 5, pp. 33-64. 
Severy B. (2003), Augustus and the Family at the Birth of the Roman Empire, Routledge, London-New York.

Veyne P. (2008), Imperium grecko-rzymskie (L’Empire gréco-romain), tłum. P. Domański, Wydawnictwo Marek Derewiecki, Kęty.

Zanker P. (1999), August i potęga obrazów (Augustus und die Macht der Bilder), tłum. L. Olszewski, Wydawnictwo Naukowe UAM, Poznań.

Zetzel E. G. (1970), New Light on Gaius Caesar's Eastern Campaign, „Greek, Roman and Byzantine Studies",11, pp. 259-266.

\section{STRESZCZenie}

\section{POSĄGI HONORYFIKACYJNE GAJUSZA I LUCJUSZA CEZARÓW}

Jedną z bardziej prestiżowych form uhonorowania członków rodziny panującej, w okresie rządów Augusta, było wystawienie na ich cześć posągów. W niniejszym artykule skoncentrowałem się na wybranych przykładach posagów dedykowanych Gajuszowi i Lucjuszowi Cezarom, wnukom i adoptowanym synom Augusta, które fundowano na ich cześć w Rzymie oraz na terenie prowincji. Przedmiotem mojego zainteresowania był przede wszystkim kontekst historyczny oraz okoliczności wystawienia tych posagów, a także z czyjej inicjatywy zostały one ufundowane. Z przeprowadzonej analizy wynika, że powody wystawienia posągu mogły być różne. Jednym z nich było np. włożenie togi męskiej (toga virilis) przez synów Augusta, z czym wiązało się oficjalne rozpoczęcie przez nich kariery politycznej. Impulsu do ufundowania wielu posagów honoryfikacyjnych dostarczyła również wizyta Gajusza na terenie prowincji wschodnich. Mieszkańcy tamtejszych regionów podkreślali w ten sposób swoją lojalność i sympatię dla dynastii panującej. W przeważającej mierze inicjatorem wystawienia grup statuarycznych ku czci obu braci na terenie prowincji byli przedstawiciele lokalnych elit lub miejscowe władze (Rada, Zgromadzenie). Nie mamy żadnych podstaw, aby zakładać jakąkolwiek ingerencję w tym względzie ze strony cesarza, bądź senatu. Wydaje się, że mieszkańcy prowincji byli doskonale zorientowani w tym, w jaki sposób wypada uhonorować najważniejszych przedstawicieli domus Augusta. O wysokiej randze tych zaszczytów świadczy m.in to, gdzie sytuowano omawiane posagi. Były one najczęściej stawiane w najbardziej prestiżowych miejscach miast Italii i prowincji, takich jak: agora, teatr, czy świątynia. W taki sposób honorowano jedynie cesarza oraz najbliższych członków dynastii panującej. Zapoczątkowany w okresie pryncypatu Augusta zwyczaj wystawiania na cześć następców tronu posąów honoryfikacyjnych, stał się za rządów kolejnych cesarzy z dynastii julijsko-klaudyjskiej powszechną praktyką. 


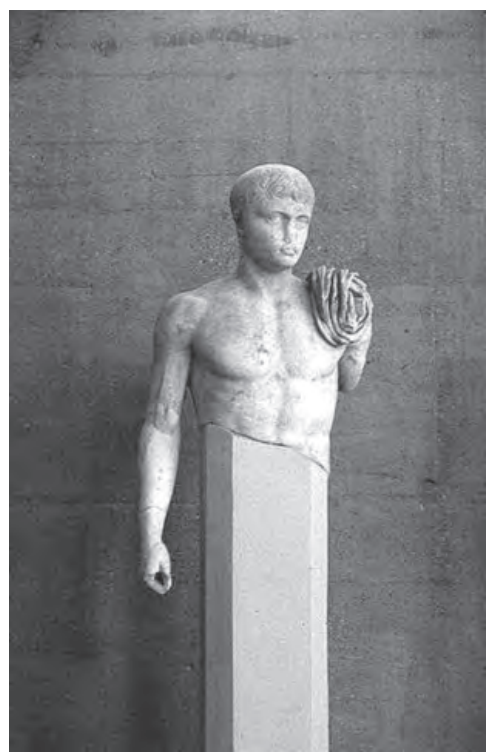

Fig. 2. A statue of Gaius Caesar, Corinth, the Archaeological Museum (Źródło: Rose 1997: pl. 187)

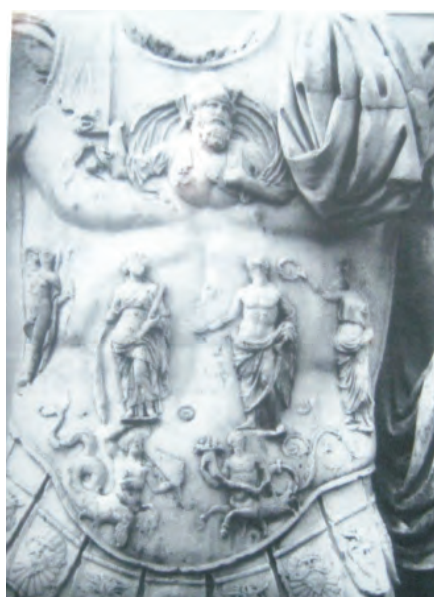

Fig. 3. A statue Lucius Caesar, Corinth, the Archaeological Museum

(Źródło: Rose 1997: pl. 186)

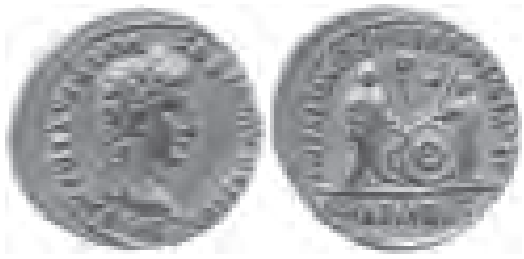

Fig. 1. Aureus (Lugdunum po 2 r. p.n.e.) (Źródło: RIC, I2, Aug. 206)

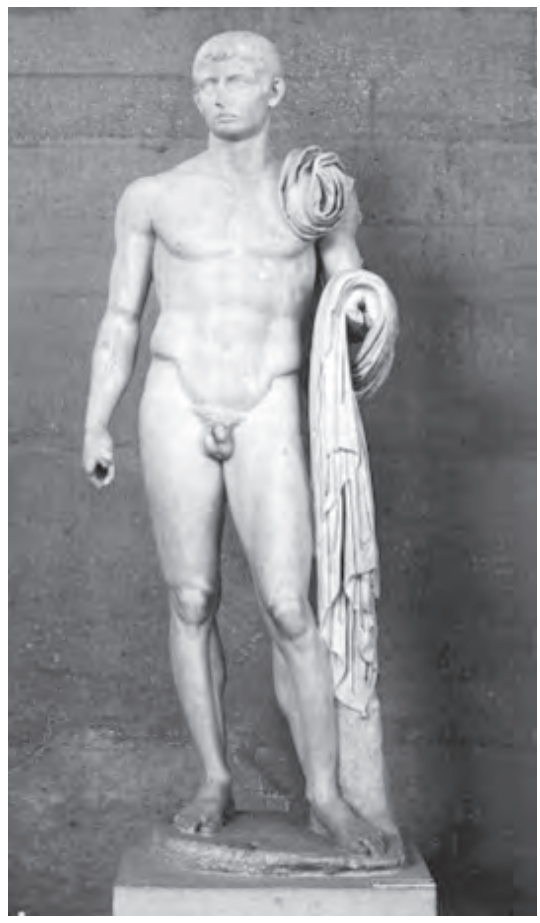

Fig. 4. The armour on a posthumousstatue of Gaius Caesar (?)

(Źródło: Zanke 1999: 225, fig. 178) 